\title{
Chapter 10 \\ Change in Floodwater Retention \\ Function of a Paddy Field Due \\ to Cultivation Abandonment \\ in a Depopulating Rural Region in Japan
}

\author{
Yota Imai, Yasunori Muto, and Mahito Kamada
}

\begin{abstract}
Flood control concept at watershed scale is used as an adaptation strategy for climate change; rainwater and floodwater should be stored in forests and agricultural lands in the watershed, rather than relying on only river systems; and paddy fields are important ecosystems for floodwater retention. The abandonment of paddy cultivation, however, is increasing year after year in Japan due to depopulation in rural regions. Through two-dimensional numerical inundation analysis, we evaluated the negative effects of topographical changes after abandonment on the floodwater retention function. The bipolarization of the inundation depth is apparent in the current topography. The areas with deepwater inundation are wider, particularly in the most downstream areas, whereas in the past, areas with shallow water were widely distributed. The peak water level in the current land use is $0.4 \mathrm{~m}$ higher than in the past. After the peak level is achieved, the water level decreases in a shorter time in the present land use than in the past. Owing to hydraulic changes after the abandonment of rice cultivation, the risk of flooding disasters for people living downstream has increased. To maintain floodwater retention function, one of the regulating services, by artificial wetlands, such as paddy fields, continuous management is essential to prevent vegetation succession. Thus, it is important to provide incentives for local people to perform the daily maintenance activities.
\end{abstract}

Keywords Abandoned paddy field · Flood management · Rural area · Depopulation · Green infrastructure

\footnotetext{
Y. Imai $(\bowtie)$

Department of Civil and Environmental Engineering, Graduate School of Advanced Technology and Science, Tokushima University, Tokushima, Japan

Department of Civil Engineering, Kobe City College of Technology, Kobe, Hyogo, Japan

Y. Muto · M. Kamada

Research Center for Management of Disaster and Environment, Tokushima University,

Tokushima, Japan

Department of Civil and Environmental Engineering, Graduate School of Technology, Industrial and Social Sciences, Tokushima University, Tokushima, Japan
}

F. Nakamura (ed.), Green Infrastructure and Climate Change Adaptation,

Ecological Research Monographs, https://doi.org/10.1007/978-981-16-6791-6_10 


\subsection{Introduction}

Owing to climate change, rainfall is increasing every year along with the magnitude and frequency of flooding (http://www.env.go.jp/earth/tekiou/report2018_full.pdf). Although floods have been controlled by strengthening river embankments and dam construction, solving this issue solely by adopting structural measures is becoming difficult from a financial viewpoint due to changes in the social condition of Japan: decreasing tax income associated with a rapid decrease in population and increasing maintenance costs for existing infrastructures (https:/www.mlit.go.jp/ sogoseisaku/maintenance/_pdf/research01_02_pdf02.pdf). Therefore, the Ministry of Land, Infrastructure, Transport and Tourism steered toward "Ryuiki-chisui" which refers to a new flood control concept at the watershed scale as an adaptation strategy for climate change (https://www.mlit.go.jp/river/kasen/ryuiki_pro/index. html): the rainwater and floodwater should be stored in forests and agricultural lands in the watershed, rather than relying on only river systems.

The use of paddy fields to reduce flood damage has been proposed as one of the flood control methods at the watershed scale (https://www.mlit.go.jp/river/ kasen/suisin/pdf/renkei_siryou02/siryou04.pdf). Paddy fields are a land use for rice production in Japan and provide several ecosystem functions (Natuhara 2013). For example, paddy fields provide a water storage function as well as a habitat for several wetland species (Katayama et al. 2015; Osawa et al. 2020), and the function has been utilized for flood disaster risk reductions (Teramura and Shimatani 2021).

The integrated management of paddies, ditches, and ridges by farmers has contributed to maintaining the water storage function of paddy fields (Yoshikawa 2014). Previous studies have been using various approaches to evaluate the water storage function of paddy fields in different regions (Matsumoto et al. 2013; Yoshikawa 2014; Muto et al. 2018; Teramura and Shimatani 2021).

In Japan, the abandonment of paddy cultivation is increasing every year due to depopulation (Osawa et al. 2013, 2016); this may have a negative effect on water storage functions due to the collapse of the ditches-ridges structure (Yoshida et al. 2013). Although several studies have evaluated changes in runoff volume from paddy fields after abandonment of cultivation, few have described the hydraulic characteristics of abandoned paddy fields. Hydraulic characteristics can be linked to sediment deposition, followed by the development of woody communities through vegetation succession. If the hydraulic characteristics of abandoned paddy fields were described, a technique which control floodwater may be developed for improvement of water storage functions. Such a technique can only be realized with a lower cost of introduction and maintenance, particularly in a depopulated rural area.

On the other hand, abandoned paddy fields have often restored to wetland/biotope and are maintained as a wildlife habitat. In wetland restoration, construction of ridges and removing shrub are conducted for keeping topographical condition flat, for retention of floodwater and rainwater. Thus, the water storage function is likely to be improved at restored abandoned paddy fields. 
In this paper, first, we clarify the negative effects of the abandonment of rice cultivation on water storage function in Shitaru District, Tsushima Island in Nagasaki Prefecture, Japan. The hydraulic characteristics of paddy fields before and after abandonment are described, compared, and discussed in terms of the process of functional decline. Second, a method of restoring the function is discussed based on the case of Tai District, Toyooka City in Hyogo Prefecture, where abandoned paddy fields have been used as wildlife habitat wetlands (Imai et al. 2020). Finally, we referred to the changes in water storage function with structural change and wetland restoration at paddy fields and to the management of abandoned paddy fields based on the comparison of two districts.

\subsection{Material and Methods}

\subsubsection{Study Area}

The study was conducted in Shitaru District in Kamiagata, Tsushima Island, in Nagasaki Prefecture $\left(34^{\circ} 34^{\prime} \mathrm{N}, 129^{\circ} 18^{\prime} \mathrm{E}\right.$; Fig. 10.1). The watershed comprises forests, paddy fields, and villages (Fig. 10.2b). The highest monthly average temperature is $26{ }^{\circ} \mathrm{C}$ in August, while the lowest is $6{ }^{\circ} \mathrm{C}$ in January. The monthly average precipitation is the highest in July $(350 \mathrm{~mm})$, followed by June $(320 \mathrm{~mm}$; (http://www.city.tsushima.nagasaki.jp/deta/post.html). The population of Shitaru District in 2020 was 73, and is estimated to decrease to 21 by 2050.

The area used to be under paddy cultivation until the 1960s (Shigehara and Shibata 2018); however, almost all paddies have been abandoned and transformed to wetland vegetation (Fig. 10.2c). The rainwater in the watershed spreads across the floodplain and eventually accumulates downstream (Fig. 10.2d).

Figure 10.3a shows the past distribution of paddy fields in the watershed. Sediments that flowed into the channels and paddy fields were removed by local farmers to maintain cultivation after flooding (Imai et al. 2019). Figure 10.3b shows the current vegetation map. Almost all paddy fields in the watershed have transformed to natural vegetation. The vegetation was classified into four types of plant communities. According to an inundation analysis, the spatial patterns of plant communities corresponded to the velocity of water and inundated depth during flooding (Imai et al. 2019).

\subsubsection{Two-Dimensional Inundation Analysis}

To obtain the current topographical conditions, aerial and field surveys were conducted from December 5 to 8, 2017. For aerial surveys, unmanned aerial vehicles (UAVs; DJI Phantom3 Pro and Phantom4 Pro) were used. To minimize errors in 

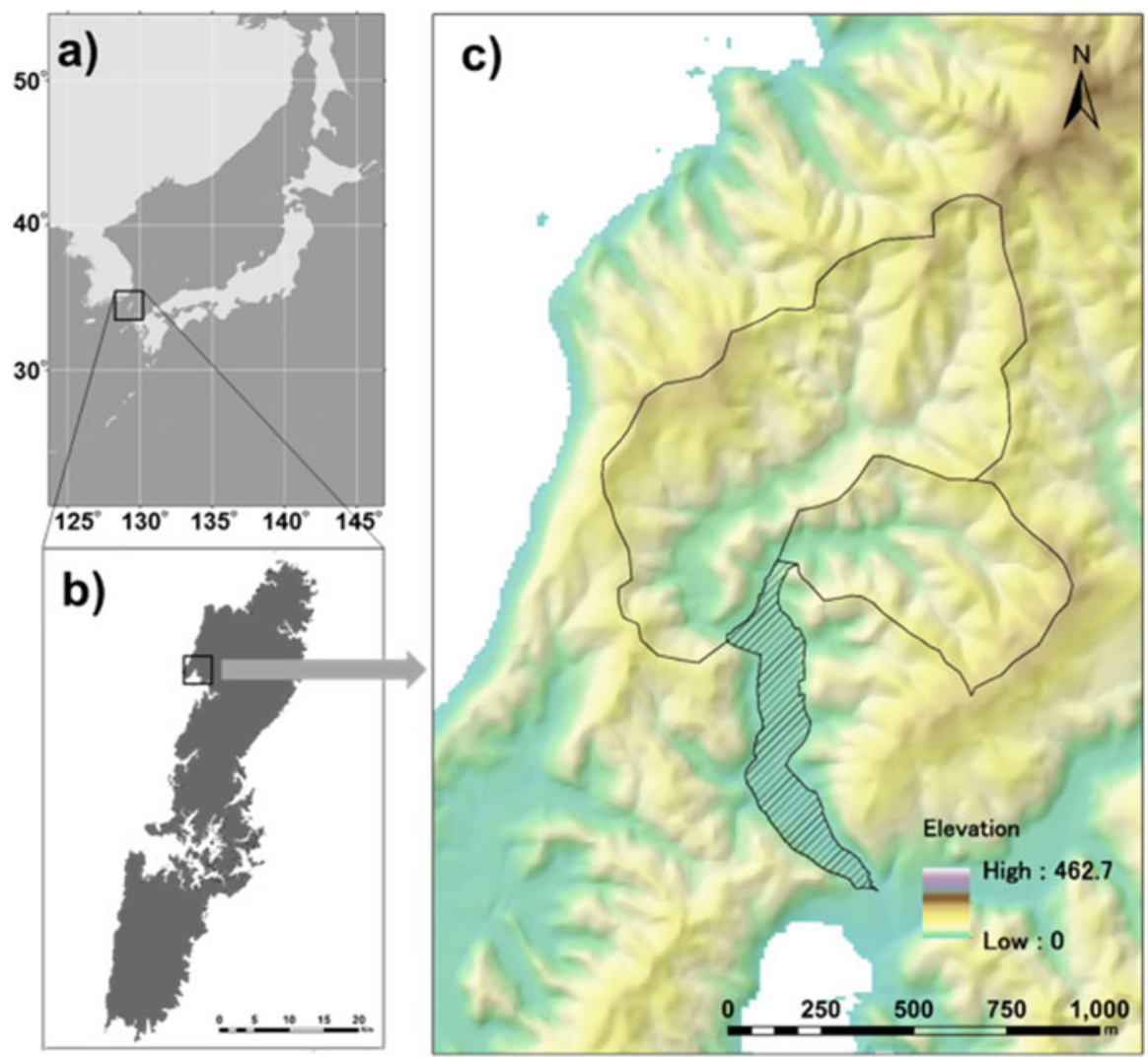

Fig. 10.1 (a) Location of Tsushima Island, Japan. (b) Map of Tsushima Island. (c) The study floodplain (hatched area in c), in Shitaru District, Tsushima Island, Japan. The black borders shown in (c) are sub-watersheds (Imai et al. 2019)

the digital terrain model, flight routes were planned with $80 \%$ overlap and $60 \%$ sidelap. A digital surface model (DSM) with a $0.8 \mathrm{~m}$ grid resolution was generated from 3447 images using the Agisoft Photoscan Pro v1.0.0 and ArcGIS v10.2.2. The parameters of Align Photos and Build Dense Cloud, structure from motionmulti view stereo (SfM-MVS) photogrammetry using Agisoft Photoscan Pro v1. 0. 0 were high, respectively. Errors in position coordinates were corrected using the coordinates from 19 ground control points (GCPs: Fig. 10.4), which were set in the watershed and measured using RTK-GNSS (TOPCON GR-2100) and Total Station. Because almost all areas of the watershed were covered by vegetation, the representative height was measured by using a handy measure for each vegetation type by field surveys on December 9, 2017; then, the digital terrain model (DTM) was obtained by subtracting the vegetation heights from the DSM. 

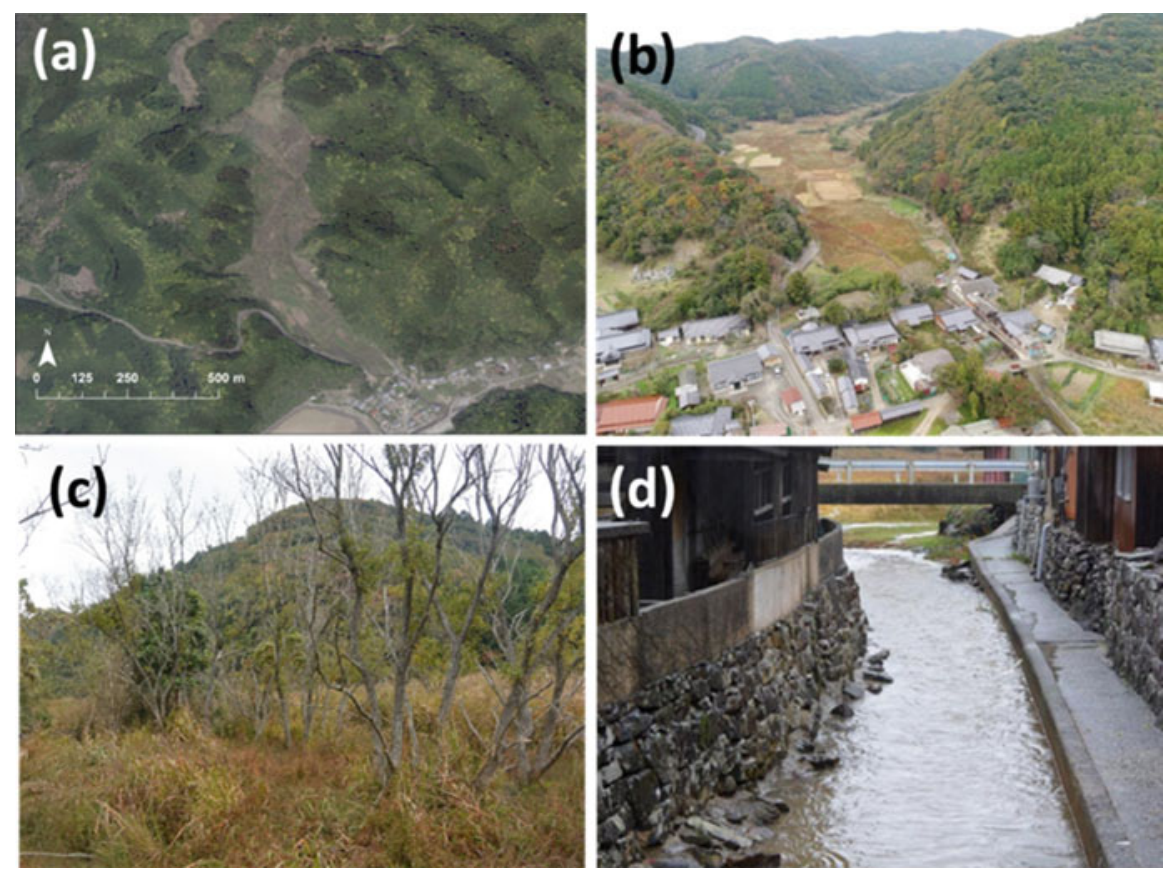

Fig. 10.2 Shitaru District. (a) The study area, (b) distribution of village and floodplain, (c) woody area, and (d) downstream area

When rice was cultivated, the farmers also maintained the ridges, and therefore, rainwater and floodwater were stored in every paddy field before overflowing into the lower fields in a step-by-step manner. Thus, the past topography was reconstructed as follows: the mean current elevation in each polygon of the paddy field was calculated from the DTM using zonal statistics (ArcGIS 10.2.2, Spatial Analyst). Then, $0.3 \mathrm{~m}$, representative height of ridges remained at study floodplain was added to the elevation of cells surrounding each paddy field to include the height of the ridge.

Differences in hydraulic characteristics before and after abandonment of cultivation were clarified by two-dimensional inundation analyses in conditions with annual maximum rainfall for past and current topography using iRIC Nays2DFlood Solver (https://i-ric.org/en/solvers/nays2dflood/). Nays2DFlood Solver enables the user to easily set the inflow conditions and topographical conditions for flood flow analysis and obtains hydraulic characteristics such as water velocity and depth at river and floodplain. 
(a)

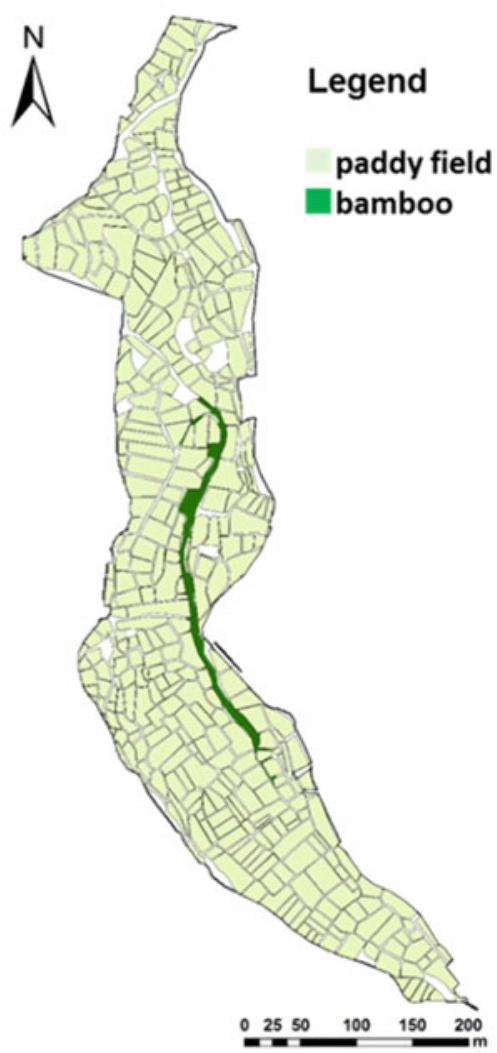

(b)

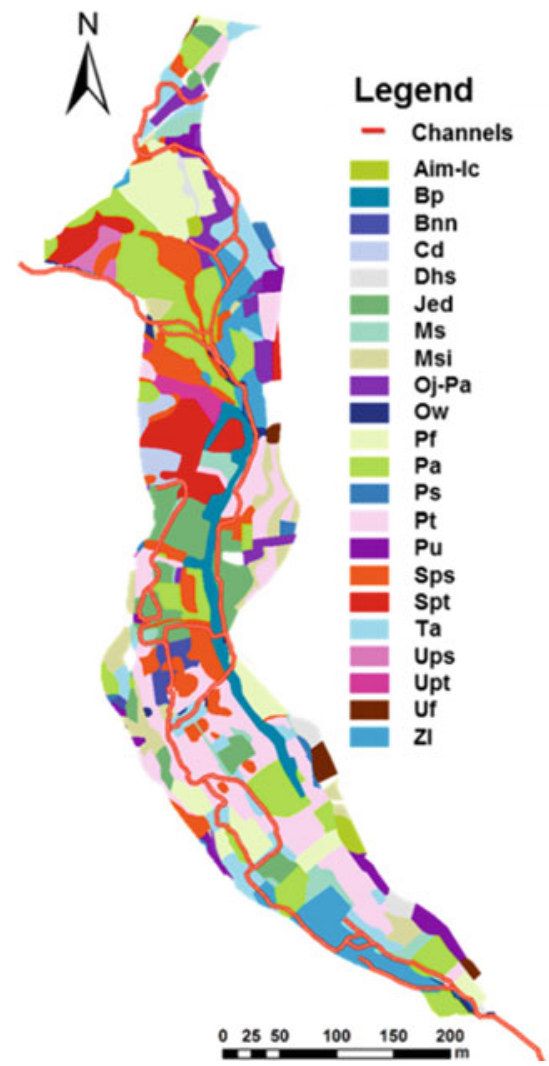

Fig. 10.3 (a) Past distribution of paddy fields and (b) current distribution of plant communities Abbreviations: Aim-Ic, Artemisia indica var. maximowiczii - Imperata cylindrica community; $\mathrm{Bp}$, bamboo plantation; Bnn, Boehmeria nivea var. nipononivea community; $\mathrm{Cd}$, Carex dispalata community; Dhs, dried herbaceous community (short); Jed, Juncus effusus var. decipiens community; Ms., Miscanthus sacchariflorus community; Msi, Miscanthus sinensis community; Oj-Pa, Oenanthe javanica - Phalaris arundinacea community; Ow, open water; Pf, paddy field; $\mathrm{Pa}$, Phragmites australis community; Ps, pioneer shrub community; Pt, Polygonum thunbergii community; Pu, Pueraria montana community; Sps, Salix pierotii community (short); Spt, Salix pierotii community (tall); Ta, Typha angustifolia community; Ups, Ulmus parvifolia community (short); Upt, Ulmus parvifolia community (tall); Uf, upland field; Zl, Zizania latifolia community (Imai et al. 2019)

For inundation analyses, the model hyetograph was generated based on records from the nearest observation points $\left(34^{\circ} 33^{\prime} \mathrm{N}, 129^{\circ} 18^{\prime} \mathrm{E}\right.$; http://www.kasen-sabo. pref.nagasaki.jp/nagasaki/main/index.php) on Tsushima Island: rainfall of $14 \mathrm{~h}$, from 12:00 on June 30 to 2:00 on July 1, 2018. The total rainfall was $73 \mathrm{~mm}$, and 
Fig. 10.4 Flight routes of UAV (yellow circles) were planned for $80 \%$ overlap and $60 \%$ sidelap and 19 GCPs were set (white circles). Black line shows study floodplain

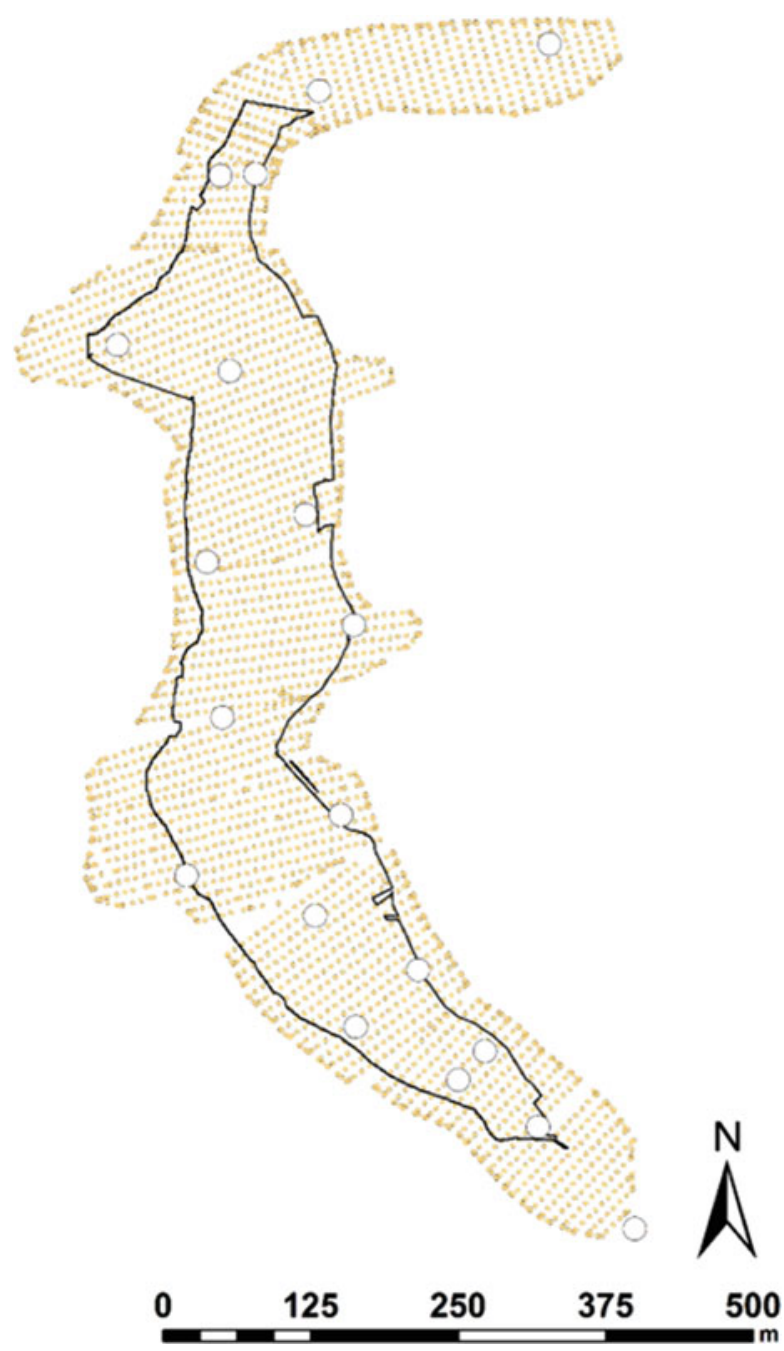

it was estimated to be 1/1-year probability based on 20-year records. The model hyetograph was produced by uniformly enlarging the annual maximum rainfall of $342 \mathrm{~mm}$ (Fig. 10.5). For the model hydrograph, discharge flowing into the target watershed from the northern and northwestern sub-watersheds was considered (Fig. 10.5). 


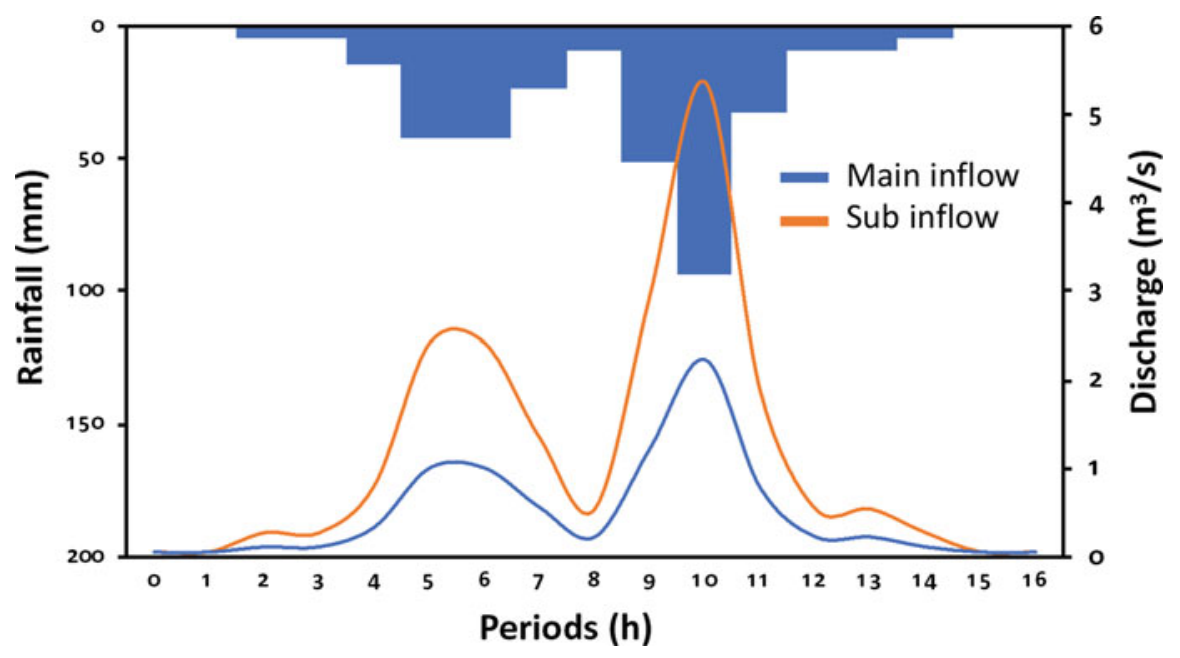

Fig. 10.5 Model hyetograph and hydrograph. Main inflow and sub-inflow show inflows from the northern and north-western sub-watersheds (Fig. 10.1(c)), respectively

\subsection{Results}

Figure 10.6 shows the hydraulic characteristics in different topographies - in the present (Fig. 10.6a) and before the abandonment of cultivation (Fig. 10.6b). The bipolarization of inundation depth is apparent in the current topography; areas without inundation and with deepwater depths (red) are wider, particularly in the most downstream area, whereas in the past, areas with shallow water (blue) were widely distributed. These results indicate that floodwater now accumulates in the most downstream area connecting to the residential area.

Figure 10.7 shows the water level at the most downstream point (see Fig. 10.2d). The peak water level in the current land use is $0.4 \mathrm{~m}$ higher than in the past. After the peak level is achieved, the water level decreases in a shorter time in the present land use than in the past. These results indicate that the water storage function has been decreased by the abandonment of cultivation.

\subsection{Discussion}

The peak water level at the downstream in the current land use is $0.4 \mathrm{~m}$ higher than in the past topographical condition (Fig. 10.7). This result shows that the hydraulic characteristics have changed, and the risk of flooding has been increased through abandonment of paddy cultivation.

The abandonment of cultivation leads to halting of farmer activities to maintain paddy field structures, and ridges collapse due to erosion (Yoshikawa et al. 2009). 
(a)

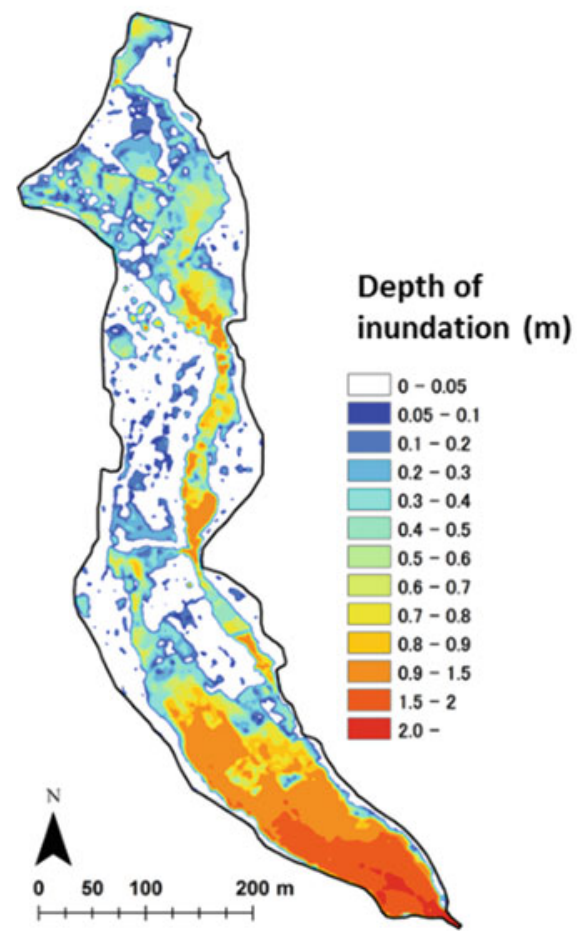

(b)

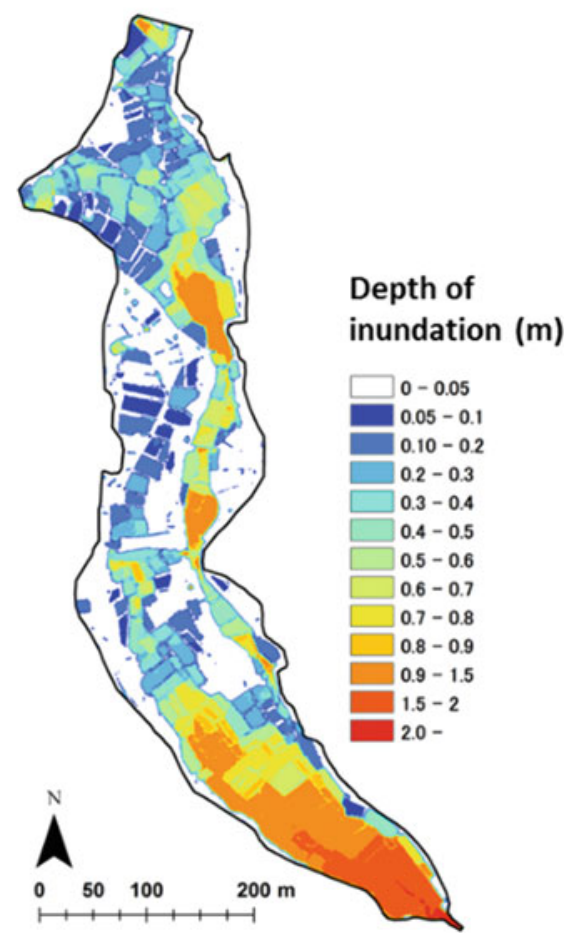

Fig. 10.6 Depth of inundation immediately after peak discharge for maximum rainfall: (a) present and (b) past land use

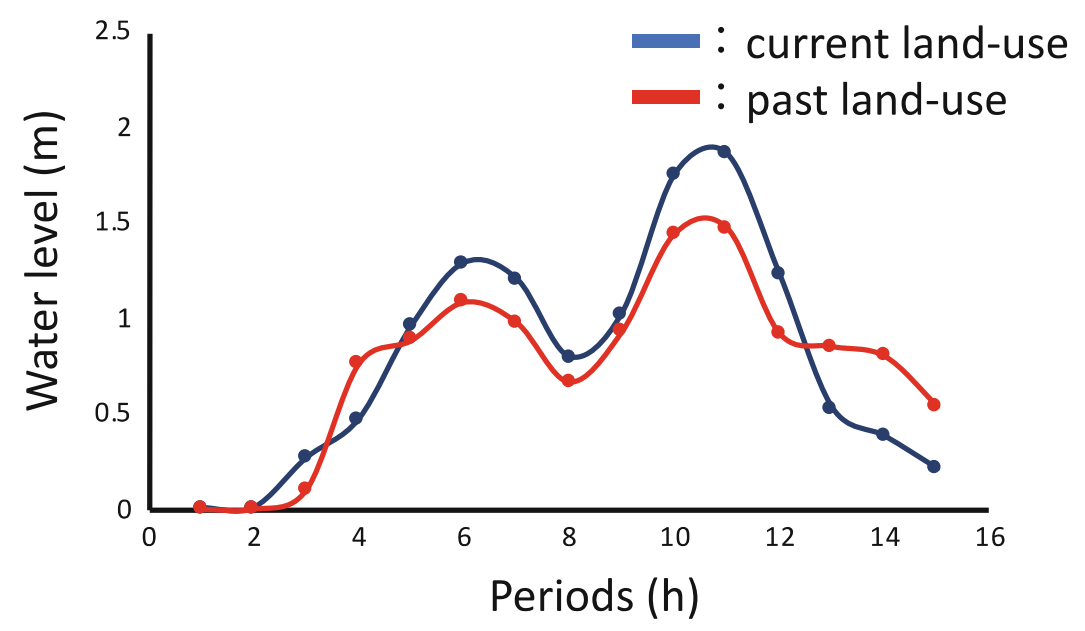

Fig. 10.7 Water level change at downstream area 
Once the ridges collapse, a water channel is formed as a natural process (Yoshida et al. 2012, 2013), and rainwater and floodwater flow into the channel as runoff. Thus, the water storage function is reduced, and the moisture condition of the area changes (Ohkuro et al. 1996).

Because of hydraulic changes after the abandonment of rice cultivation, natural vegetation has established (Imai et al. 2019), but the risk of flooding disasters for people living in downstream areas has increased. The same situation has occurred in many rural regions in Japan undergoing depopulation. It is necessary to adopt appropriate measures against flood disasters in these regions, where little administrative support can be obtained.

\subsection{Mitigating Flood Risk Using Abandoned Paddy Field Through Wetland Restoration}

At Tai District in Toyooka City, Hyogo Prefecture, Japan (35 $38^{\prime} 37.9 / 1 \mathrm{~N}$ $134^{\circ} 50^{\prime} 41.5 / / \mathrm{E}$; Figs. 10.7 and 10.8 ), where the population is estimated to decrease from 136 in 2020 to 73 by 2050, abandoned paddy fields have restored to
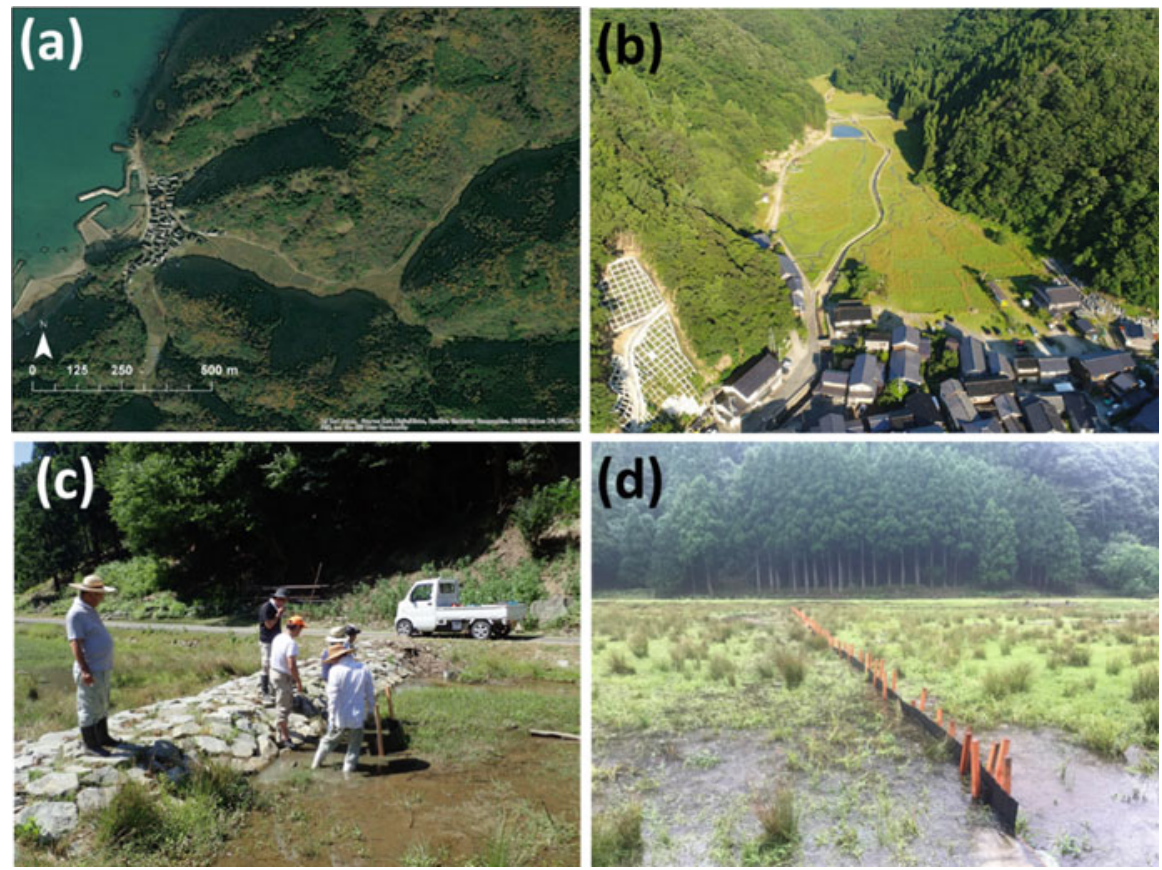

Fig. 10.8 Tai District. (a) Study site, (b) distribution of village and floodplain, and (c, d) weirs and flashboards maintained by local people and volunteers for wetland improvement 
wetland/biotope and are maintained as feeding sites for the Oriental white stork (Ciconia boyciana). This is an endangered bird protected by the government and local people, through collaborative activities by local people and volunteers from outside the district.

The wetlands have been used as a floodwater retention area. These structures reduce the flow velocity during flooding. In addition to voluntary work, overflow levees and small water reservoirs were constructed in the uppermost stream of the wetland with the support of Toyooka City.

The results of two-dimensional flood flow analysis for $1 / 30$-year rainfall showed that $22 \%$ of peak discharge was stored in abandoned paddy fields (Fig. 10.9; Imai et al. 2020) and $25 \%$ of the total discharge was stored in the wetland (Fig. 10.10; Imai et al. 2020). Thus, managed abandoned paddy fields can be used as floodwater retention areas, and water storage function can be improved by wetland restoration for flood disaster reduction.

Fig. 10.9 Temporal changes in discharge (Imai et al. 2020). Outflow shows the discharge at the downstream boundary and inflow shows the discharge at the upstream boundary

Fig. 10.10 Comparison of floodwater volume between the calculated area (total) and abandoned paddy fields on its area during flooding (Imai et al. 2020)
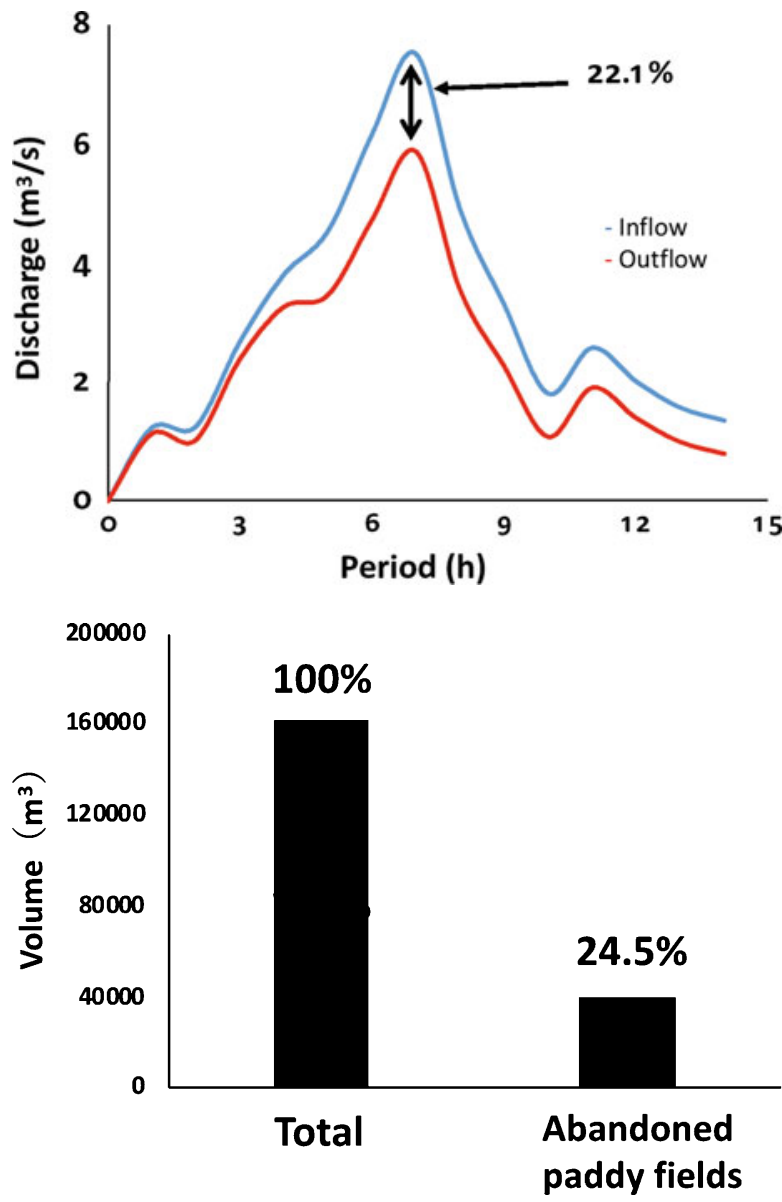


\subsection{Changes in Water Storage Function with Structural Change and Their Management at Abandoned Paddy Fields}

Paddy fields provide provisioning services for rice cultivation as well as regulating services via water storage functions through maintenance of ditches and ridges structure. However, the water storage function of paddy fields is decreased by structural changes after abandonment of cultivation; the quality of regulating services worsens after relinquishing provisioning services, as in the case of Shitaru. In the case of Tai, the water storage function was provided at the restored abandoned paddy fields with weirs and flashboards introduced by the local people due to habitat improvement for supporting Oriental white storks. Thus, the water storage function decreases from cultivated paddy fields to abandoned paddy fields, but its function of abandoned paddy fields could be improved through wetland restoration.

At the Tai District, supporting Oriental white storks was an incentive for local people and volunteers from outside the district, rather than flood control. To maintain regulating services of artificial wetlands, such as abandoned paddy fields, continuous management to prevent vegetation succession is essential. Hence, it is important to provide monetary compensation and to emerge incentives such as recovery of biodiversity for local people to contribute to this management (Satake 2014). A technique that emerges both water storage function and biodiversity conservation should be developed with adaptive management approach.

Acknowledgments We are grateful to the local people of the Shitaru and Tai districts, who allowed us to carry out our survey and provided useful information in this regard. This study was supported by the Environment Research and Technology Development Fund (4-1504, 4-1805) of the Ministry of the Environment, Japan.

\section{References}

Imai Y, Shigehara N, Shibata S, Muto Y, Kamada M (2019) Spatial pattern of plant communities in relation to hydraulic conditions at wetland emerged at abandoned paddy fields. In: Eproceedings of the 38th IAHR World Congress, 1-6 September, 2019, Panama City, Panama, pp 3311-3320

Imai Y, Mitsuhashi H, Kamada M, Muto Y (2020) Fundamental study on water storage function of abandoned paddy field on small river floodplain. Annu J Hydraulic Eng JSCE 65:793-798; [In Japanese with English Abstract]

Katayama N, Baba YG, Kusumoto Y, Tanaka K (2015) A review of post-war changes in rice farming and biodiversity in Japan. Agric Syst 132:73-84

Matsumoto T, Fukuoka S, Sumi T (2013) Estimation of flood storage volume in the three retarding basins along the tone river. Annu J Hydraulic Eng JSCE 69(4):793-798; [In Japanese with English Abstract] 
Muto Y, Kotani S, Miyoshi M, Kamada M, Tamura T (2018) Retarding capacity change of wetland paddy fields due to house land development -utilizing paddy fields as green infrastructure against flood. In: Proceedings of the 21th IAHR-APD congress 2018, 8pp

Natuhara Y (2013) Ecosystem services by paddy fields as substitutes of natural wetlands in Japan. Ecol Eng 56:97-106

Ohkuro T, Matsuo K, Nemoto M (1996) Vegetation dynamics of abandoned paddy fields and their levee slopes in mountainous regions of Central Japan. Jpn J Ecol 46:245-256; [In Japanese with English Abstract]

Osawa T, Kohyama K, Mitsuhashi H (2013) Areas of increasing agricultural abandonment overlap the distribution of previously common, currently threatened plant species. PLoS One 8(11):e79978

Osawa T, Kohyama K, Mitsuhashi H (2016) Multiple factors drive regional agricultural abandonment. Sci Total Environ 542:478-483

Osawa T, Nishida T, Oka T (2020) Paddy fields located in water storage zones could take over the wetland plant community. Sci Rep 10(1):1-8

Satake S (2014) Habitat creation and restoration in collaboration with local residents. Reintroduction 3:25-27; [In Japanese with English Abstract]

Shigehara N, Shibata S (2018) The transition of biological resources use and land use in the 1950s and later in Shitaru, Tsushima city, Nagasaki prefecture. Jpn Inst Landscape Architect 81(5):699-702; [In Japanese with English Abstract]

Teramura J, Shimatani Y (2021) Advantages of the open levee (Kasumi-Tei), a traditional Japanese river technology on the Matsuura river, from an ecosystem-based disaster risk reduction perspective. Water 13(4):480

Yoshida T, Masumoto T, Horikawa N (2012) Changes in rainfall-runoff characteristics of small watersheds due to cultivation conditions of hilly paddies. Irrigation Drainage Rural Eng J 80(2):117-124; [In Japanese with English Abstract]

Yoshida T, Masumoto T, Horikawa N, Minakawa H (2013) Modelling of short-term runoff processes in watersheds dominated by hilly paddies. Irrigation Drainage Rural Eng J 81(3):235244; [In Japanese with English Abstract]

Yoshikawa N (2014) Can paddy fields mitigate flood disaster? Possible use and technical aspects of the paddy field dam. In: Social-ecological restoration in Paddy-dominated landscapes. Springer, Tokyo, pp 197-207

Yoshikawa N, Nagao N, Misawa S (2009) Watershed scale evaluation of flood mitigation function of paddy fields installed with runoff control devices. Irrigation Drainage Rural Eng J 261(3):4448; [In Japanese with English Abstract]

Open Access This chapter is licensed under the terms of the Creative Commons Attribution 4.0 International License (http://creativecommons.org/licenses/by/4.0/), which permits use, sharing, adaptation, distribution and reproduction in any medium or format, as long as you give appropriate credit to the original author(s) and the source, provide a link to the Creative Commons license and indicate if changes were made.

The images or other third party material in this chapter are included in the chapter's Creative Commons license, unless indicated otherwise in a credit line to the material. If material is not included in the chapter's Creative Commons license and your intended use is not permitted by statutory regulation or exceeds the permitted use, you will need to obtain permission directly from the copyright holder. 